\title{
Meningkatkan Minat Membaca melalui Gerakan Literasi Membaca bagi Siswa Sekolah Dasar
}

\author{
Arum Nisma Wulanjani1*, Candradewi Wahyu Anggraeni1 \\ ${ }^{1}$ Fakultas Keguruan dan Ilmu Pendidikan, Universitas Tidar. \\ *Coresponding author: arum_nisma@ untidar.ac.id
}

\section{ARTICLE INFO}

Article history:

Received: Mei 2019

Accepted: September 2019

\section{Keywords:}

membaca, minat

membaca, literasi

membaca

\begin{abstract}
ABSTRAK
Membaca merupakan salah satu hal yang penting dalam segala macam proses pembelajaran. Melalui membacalah berbagai ilmu pengetahuan, yang dapat mengantarkan pada kesuksesan, bisa kita dapatkan. Artikel ini bertujuan untuk mendiskripsikan implementasi gerakan literasi membaca bagi siswa sekolah dasar di SDN Rejowinangun Selatan 3 dan SDN Rejowinangun Selatan 4. Hasil observasi awal menunjukkan bahwa guru-guru pada kedua sekolah tersebut masih pasif dalam melaksanakan gerakan literasi membaca. Guru-guru di SDN tersebut belum secara aktif memberi perhatian pada upaya peningkatan literasi membaca para siswa. Melalui berbagai kegiatan yang menyenangkan bagi siswa, peneliti berusaha untuk menumbuhkan kecintaan membaca siswa melalui penerapan gerakan literasi membaca. Kegiatan dilaksanakan 15 menit sebelum pembelajaran dimulai. Hasil penelitian menunjukkan bahwa melalui kegiatan-kegiatan yang menyenangkan sebagai upaya penerapan gerakan literasi membaca, para siswa menjadi lebih antusias dan termotivasi untuk lebih meningkatkan minat dalam membaca
\end{abstract}

\section{PENDAHULUAN}

Di era pendidikan 4.0, minat baca siswa khususnya siswa di level sekolah dasar perlu ditingkatkan (Handayani, Adisyahputra, \& Indrayanti, 2018). Era pendidikan 4.0 menjadi tantangan tersendiri tak terkecuali bagi pihak sekolah dasar dalam membentengi siswa dari dampak negatif derasnya penggunaan teknologi terutama dalam keseharian siswa. Era pendidikan 4.0 merupakan era modern dimana adanya sistem digitalisasi hampir dalam segala aspek kehidupan, tak terkecuali dalam aspek pendidikan. Dengan perkembangan teknologi yang semakin pesat, tentunya hal tersebut baik secara langsung maupun tidak langsung akan menjadi tantangan tersendiri bagi para siswa.

Pendidikan 4.0 tidak hanya berfokus pada pemanfaatan teknologi, akan tetapi minat baca siswa juga perlu ditingkatkan untuk menyongsong Pendidikan 4.0. Derasnya arus informasi dan teknologi di era pendidikan 4.0 ini berdampak pada semakin terbatasnya waktu yang dimiliki para siswa untuk membaca. Padahal, kemampuan literasi siswa 
dalam membaca tentunya dapat sangat diperlukan bagi siswa untuk tetap dapat mengikuti segala perkembangan terutama yang terkait dengan dunia pendidikan mereka Yuriza, Adisyahputra, \& Sigit, 2018; Juhanda, \& Maryanto, 2018).

Pada saat ini sesungguhnya para siswa dihadapkan pada pada persoalan bagaimana mengatasi keterbatasan waktu dan dapat membaca dalam waktu yang relatif singkat tetapi dapat memperoleh informasi yang sebanyak-banyaknya (Rahmania, Miarsyah, \& Sartono, 2015). Bagaimana dapat melakukan kegiatan membaca secara efektif tanpa membuang-buang waktu. Selaras dengan pernyataan tersebut, terlihat bahwa kemampuan literasi membaca sangatlah dibutuhkan para siswa seiring dengan pesatnya perkembangan informasi dan teknologi di masa sekarang ini. Hanggi (2016) menyatakan bahwa literasi membaca dapat menjadi sarana bagi siswa dalam mengenal, memahami, dan menerapkan ilmu yang didapatkan di sekolah. Literasi dasar, termasuk lilterasi membaca, sudah selayaknya perlu ditanamkan sejak pendidikan dasar (Ristanto, Zubaidah, Amin \& Rochman, 2017). Hal tersebut diperlukan supaya para siswa dapat meningkatkan kemampuannya dalam upaya mengakses informasi ataupun ilmu pengetahuan. Literasi akan mengantarkan para siswa untuk memahami suatu pesan (Hernowo, 2003). Pentingnya literasi juga dismapiakan oleh Kemendikbud (2016) bahwa budaya literasi yang tertanam dalam diri peserta didik mempengaruhi tingkat keberhasilan dan kemampuan peserta didik untuk memahami informasi secara analitiss, kritis, dan reflektif. Pemerintah juga telah mencanangkan program Gerakan Literasi Bangsa (GLB) yang bertujuan untuk menumbuhkan budi pekerti anak melalui budaya literasi (membaca dan menulis).

Ironisnya, pesatnya perkembangan informasi dan teknologi justru membawa bangsa ini kemunduran dalam hal minat membaca. Siswa-siswa kini lebih sering menghabiskan waktu untuk menonton TV ataupun menghabiskan waktu mereka di depan layar gadget (Ane, 2015). Hasil observasi di lapangan juga menunjukkan bahwa SDN Rejowinangun Selatan 3 dan SDN Rejowinangun Selatan 4 Magelang Selatan rupanya belum menerapkan secara maksimal Gerakan Literasi Sekolah. Hal ini berarti bahwa pihak sekolah belum mengupayakan aksi-aksi yang dapat mendukung dan meningkatkan terutama kemampuan literasi membaca siswa. Minat membaca para siswa di SDN tersebut tergolong masih rendah. Mereka kurang tertarik untuk membaca berbagai ragam jenis teks.

Berdasarkan kondisi tersebut, penelitian ini berupaya untuk bisa menawarkan dan menyajikan kegiatan-kegiatan yang menarik dalam upaya menarik minat para siswa dalam meningkatkan minat membaca khususnya melalui gerakan literasi membaca. Melalui gerakan literasi membaca diharapkan para siswa akan dapat mengembangkan dan merangsang kemampuan literasi membaca mereka, kreativitas, imajinasi, dan juga pengetahuan mereka.

Pentingnya kemampuan literasi telah sering diteliti pada penelitian-penelitian sebelumnya. Upaya gerakan literasi sekolah merupakan suatu bentuk dukungan kepada pemerintah dalam upaya menanamkan budi pekerti dari semenjak pendidikan dasar. Salah satu penelitian tersebut yaitu penelitian yang dilakukan oleh Suyono,dkk (2017). Dalam penelitian tersebut, mereka memfokuskan penelitian pada implementasi Gerakan Literasi Sekolah (GLS) di sekolah dasar. Dari hasil penelitian mereka ditemukan polapola dalam implementasi Gerakan Literasi Sekolah, yaitu pola kegiatan literasi pada buku tematik dan pola kegiatan literasi di sekolah.

Penelitian terkait dengan gerakan literasi yang selanjutnya adalah penelitian dari Apriani dan Aryani (2017). Penilitian ini menggunakan pop up book sebagai media dalam upaya membangun budaya literasi. Mereka melakukan pembelajaran literasi dengan menggunakan pop up book. Dari hasil penelitian tersebut terungkap bahwa embelajaran literasi dengan pop up book memberikan kontribusi yang positif siswa terhadap pembelajaran literasi sekaligus membangun budaya literasi guna 
mengembangkan kretavitas, menambah pengetahuan, merangsang imajinasi dan menumbuhkan rasa cinta membaca.

Dari kedua penelitian terdahulu dapat disimpulkan bahwa dengan menerapkan kegiatan yang tepat dalam upaya peningkatan literasi siswa dapat membawa dampak positif bagi siswa khususnya terkait dengan budaya literasi di sekolah. Namun dari kedua penelitian tersebut belum menilik lebih lanjut lagi mengenai penerapan gerakan literasi di sekolah. Untuk itu, penelitian ini hadir untuk memberikan pengetahuan-pengetahuan baru terutama terkait dengan berbagai kegiatan menarik yang dapat diterapkan di sekolah dalam upaya penerapan gerakan literasi khususnya literasi membaca. Selain itu penelitian ini juga memberikan tindak lanjut yang dapat diadopsi oleh sekolah-sekolah lain sebagai upaya menjaga terlaksananya gerkana literasi membaca secara berkelanjutan di sekolah.

\section{METODE}

Artikel ini menggunakan metode penelitian kualitatif dalam ranah penelitian studi kasus. Menurut Gall dkk (2003), penelitian studi kasus merupakan metode penelitian berfokus pada sebuah fenomena untuk dikaji atau dideskripsikan secara mendalam. Dalam hal ini, peneliti mengkaji sebuah fenomena tentang implementasi gerakan literasi membaca bagi siswa sekolah dasar di SDN Rejowinangun Selatan 3 dan SDN Rejowinangun Selatan 4.

Partisipan dalam penelitian ini adalah 50 siswa kelas 5 yang terbagi menjadi 25 siswa di SDN Rejowinangun Selatan 3 dan 25 siswa SDN Rejowinangun Selatan 4. Instrumen penelitian yang digunakan yaitu observasi dan wawancara. Peneliti melaksanakan observasi terkait upaya pelaksanaan gerakan literasi di sekolah tersebut. Selain itu, peneliti menerapkan beberapa metode-metode atau kegiatan penunjang untuk mendukung upaya gerakan literasi membaca. Wawancara juga dilaksanakan untuk mengetahui perspektif siswa terkait kegiatan peningkatan minat membaca.

\section{HASIL DAN PEMBAHASAN}

Berdasarkan kegiatan observasi, peneliti menerapkan beberapa kegiatan peningkatan minat baca siswa untuk mendukung gerakan literasi membaca bagi siswa. Kegiatan yang diterapkan peneliti seperti Kegiatan 15 menit membaca sebelum memulai kegiatan belajar mengajar.

\section{a. Kegiatan 15 Menit Membaca}

Kegiatan 15 menit membaca bertujuan untuk meningkatkan minat baca siswa sehingga program gerakan literasi dapat berjalan dengan sukses. Berikut deskripsi kegiatan 15 menit membaca yang diterapkan oleh peneliti kepada para siswa.

Tabel 1. Deskripsi Kegiatan 15 Menit Gerakan Literasi

\begin{tabular}{|l|l|l|}
\hline No & Detail Kegiatan & Alokasi Waktu \\
\hline 1 & Buku Bacaan diberikan ke siswa. & 1 menit \\
\hline 2 & Siswa membaca buku bacaan. & 9 menit \\
\hline 3 & $\begin{array}{l}\text { Kegiatan pilihan: } \\
\text { a. Siswa menceritakan kembali tentang isi buku } \\
\quad \text { bacaan kepada teman sebangku. }\end{array}$ & 5 menit \\
& $\begin{array}{l}\text { biswa melaksanakan kegiatan peningkatan minat } \\
\text { baca. }\end{array}$ & \\
\hline
\end{tabular}

Dalam kegiatan 15 menit Gerakan Literasi, peneliti menerapkan beberapa metode peningkatan minat baca seperti pembuatan Scrapbook. Scrapbook merupakan salah satu metode seni menempel gambar atau foto pada media kertas. Penerapan metode peningkatan minat 
baca melalui Scrapbook terdiri dari beberapa langkah seperti berikut.

1. Siswa membentuk kelompok yang terdiri dari empat orang.

2. Siswa membaca buku bacaan yang telah dibagikan dalam waktu 9-10 menit.

3. Siswa mengumpulkan buku bacaan.

4. Siswa memperoleh potongan gambar tentang cerita di buku bacaan.

5. Siswa mendapatkan media kertas berwarna, alat tulis, dan lem untuk Scrapbook yang telah dibagikan ke setiap kelompok.

6. Siswa menyusun potongan gambar secara urut berdasarkan cerita di buku bacaan dalam waktu sekitar 3 menit.

7. Siswa menulis minimal satu kalimat yang mendeskripsikan gambar yang telah disusun.

8. Siswa mempresentasikan karya Scrapbook mereka.

9. Siswa mengumpulkan Scrapbook mereka di Pojok Baca di kelas.

Berdasarkan observasi kelas, para siswa antusias dalam mengikuti kegiatan peningkatan minat baca dengan metode Scrapbook. Hal ini ditunjukan dari keaktifan siswa dalam membuat Scrapbook. Berikut beberapa dokumentasi tentang penerapan metode Scrapbook untuk meningkatkan minat baca para siswa.

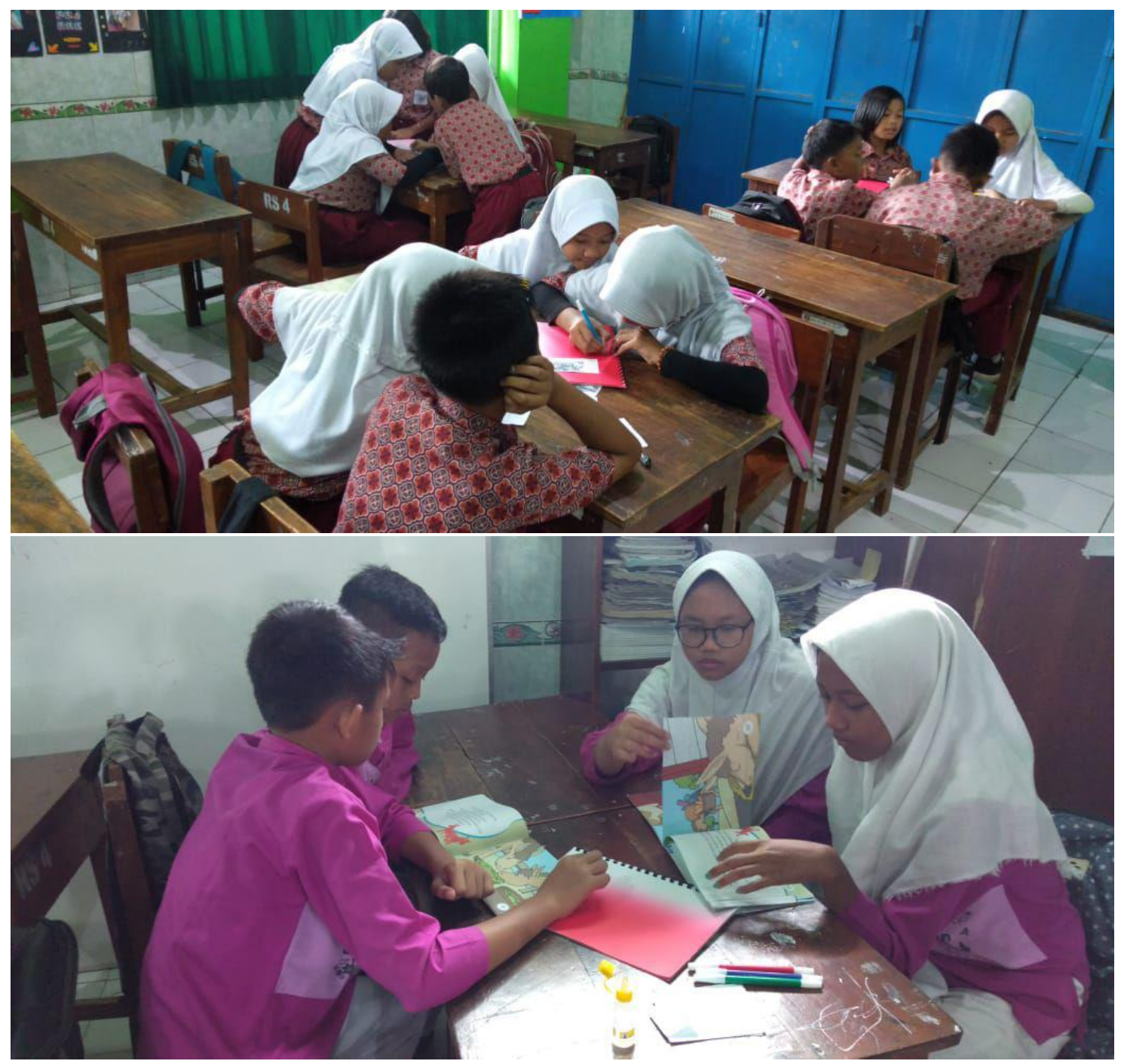

Berdasarkan hasil wawancara dengan para siswa terkait kegiatan 15 menit membaca, siswa berpendapat bahwa kegiatan 15 menit membaca adalah kegiatan yang 
menyenangkan khususnya ketika metode Scrapbook diterapkan dalam kegiatan 15 menit membaca. Berikut beberapa data wawancara dengan siswa.

Data 1

"Aku senang dengan kegiatan ini, buku ceritanya bagus dan bergambar."

Data 2

"Saya suka menyusun gambar dan bercerita setelah baca buku ceritanya."

Data 3

"Saya senang membaca, apalagi menyusun gambar bersama teman-teman."

Data 4

"Saya suka membaca buku cerita dan menyusun gambar, kegiatannya seru."

Data 5

"Saya senang cerita kembali setelah menyusun gambar tadi."

Data 1 sampai dengan Data 5 menunjukan bahwa para siswa merasa senang dan tertarik dengan kegiatan 15 Menit Membaca. Hal ini menunjukan bahwa perlu mengoptimalkan kegiatan 15 Menit Membaca yang sudah diterapkan oleh pihak sekolah. Penanggung jawab kegiatan 15 Menit Membaca di setiap sekolah dapat menerapkan metode-metode peningkatan minat baca siswa seperti dengan penggunaan metode Scrapbook, Retelling story, ataupun yang lainnya. Dengan mendayagunakan kegiatan 15 Menit Membaca, program Gerakan Literasi Membaca dapat berjalan dengan sukses dan lancar.

\section{b. Pojok Baca}

Pojok Baca merupakan salah satu program yang telah diinisiasi pihak Sekolah Dasar untuk meningkatkan minat baca siswa. Pojok Baca terdapat disetiap sudut kelas dengan koleksi buku-buku cerita dan buku-buku penunjang mata pelajaran. Berdasarkan wawancara dengan guru, manfaat Pojok Baca adalah sebagai berikut.

a. Pojok Baca merupakan alternatif bagi siswa untuk gemar membaca.

b. Pojok Baca menjadikan siswa dapat mengakses buku cerita atau buku penunjang mata pelajaran secara mudah.

c. Pojok Baca dapat mendekatkan siswa dengan buku.

d. Pojok Baca dapat dijadikan sarana untuk mendukung kegiatan belajar.

Dengan mengoptimalkan Pojok Baca, Gerakan Literasi Membaca dapat berjalan dengan lancar. Perlu adanya dukungan dari berbagai pihak seperti Kepala Sekolah, Guru, Penanggung Jawab Gerakan Literasi, dan para siswa untuk mengoptimalkan Pojok Baca sebagai salah satu program Gerakan Literasi di Sekolah Dasar. Berikut dokumentasi Pojok Baca.

\section{KESIMPULAN}

Gerakan Literasi Membaca bagi siswa Sekolah Dasar merupakan program yang perlu didukung oleh seluruh pihak di sekolah. Dalam penelitian ini, hasil penelitian menunjukan bahwa kegiatan 15 Menit Membaca dengan berbagai metode peningkatan minat baca dan Pojok Baca merupakan program peningkatan minat baca untuk mendukung Gerakan Literasi Membaca. Dengan mengoptimalkan Gerakan Literasi Membaca, siswa dan guru akan mendapatkan banyak manfaat untuk mendukung kegiatan 
belajar dan mengajar.

\section{DAFTAR PUSTAKA}

Ane, P. 2015. Membangun kualitas bangsa dengan budaya literasi. Prosiding Seminar Nasional Bulan Bahasa UNIB 2015.

Apriani, An Nisa dan Ariyani, Y. D. 2017. "Membangun Budaya Literasi Permulaan bagi Siswa SD Kelas Awal melalui Pop Up Book."

Handayani, G., Adisyahputra, A., \& Indrayanti, R. (2018). Correlation between integrated science process skills, and ability to read comprehension to scientific literacy in biology teachers students. Biosfer: Jurnal Pendidikan Biologi, 11(1), 22-32.

Hanggi, Olovia Herlina. 2016. "Tiga Perubahan Kecil dalam Literasi Sekolah." Membumikan Gerakan Literasi di Sekolah. Yogyakarta: Lembaga Ladang Kata.

Hernowo, ed. 2003. Quantum Reading: Cara Cepat nan Bermanfaat untuk Merangsang Munculnya Potensi Membaca. Bandung: Mizan Learning Center.

Juhanda, A., \& Maryanto, Y. (2018). The emergence of biological problems in electronic school books (bse) class $\mathrm{x}$ reviewed from the scientific knowledge domain of scientific literacy. Biosfer: Jurnal Pendidikan Biologi, 11(2), 121-125.

Rahmania, S., Miarsyah, M., \& Sartono, N. (2015). The difference scientific literacy ability of student having field independent and field dependent cognitive style. Biosfer: Jurnal Pendidikan Biologi, 8(2), 27-34.

Ristanto, R. H., Zubaidah, S., Amin, M., \& Rocman. (2017). Scientific literacy of students learned through guided inquiry. International Journal of Research and Review, 4(5), 23-30.

Yuriza, P. E., Adisyahputra, A., \& Sigit, D. V. (2018). Correlation between higher-order thinking skills and level of intelligence with scientific literacy on junior high school students. Biosfer: Jurnal Pendidikan Biologi, 11(1), 13-21.

Suyono, S., Harsiati, T., \& Wulandari, I. S. (2017). Implementasi Gerakan Literasi Sekolah pada Pembelajaran Tematik di Sekolah Dasar. Sekolah Dasar: Kajian Teori dan Praktik Pendidikan, 26(2), 116-123. 